\title{
Jövőnk vagy végzetünk? (A mesterséges intelligenciáról)
}

\begin{abstract}
A tanulmány amellett érvel, hogy a mesterséges intelligencia (MI) nem a jövő kérdése, hanem már most is a mindennapi életünk része. Az a széles körben elterjedt félelem azonban, hogy uralni fog minket, nem eléggé megalapozott.

Jóllehet az MI szakemberek többsége úgy gondolja, hogy a szuperintelligencia néhány évtizeden belïl megvalósulhat, mégis komoly akadályok állnak előttünk. Hosszú távon azonban a szingularitás valószínűsíthetőleg bekövetkezik, és ezzel részesei leszünk az Univerzum fejlődésének.
\end{abstract}

A legtöbb ember számára valami majdani, misztikus, rejtélyes dolgot jelent, holott már jelenünk, mindennapi életünk része. Anonim algoritmusok döntik el, hogy amikor az internet keresőjébe beírunk egy tárgyszót, a tengernyi rendelkezésre álló anyag milyen sorrendben jelenjen meg - korábbi érdeklődésünkre tekintettel; vagy milyen reklámok kísérjék a keresést, korábbi vásárlásainkat figyelembe véve. A mesterséges intelligencia (MI) ma már tud járművet vezetni, tőzsdei ügyleteket lebonyolítani, befektetési tanácsokat adni, pénzmosást felderíteni, könyvelést és mindenféle adatfeldolgozást végezni, adathalmazból a kívánt információt megkeresni, újságot szerkeszteni, tömegben arcokat felismerni, arcok alapján jellemzést adni, egy beteg diagnózisát felállítani és a szükséges terápiát kidolgozni, röntgenfelvételeket kielemezni, jogi precedenseket keresni, egy per (vagy perindítás) kimenetelét megjósolni, idegen nyelvű szöveget fordítani, beszédet felismerni és emberi beszédet modulálni, Bach-korálokat komponálni, neves festők stílusában festeni és verset írni. Képes háztartásunkat okossá tenni, idős emberek szórakoztató társául szegődni, tulajdonosának az internet szolgáltatásaival kapcsolatos szóbeli kéréseit teljesíteni (lásd Alexa és Siri, a lakásba vagy autóba telepített internetes web-robotok), webrobotként tulajdonosa nevében chatelni, helyette vitatkozni, ügyeit intézni, online vásárlás esetén alkudozni, a világhálón párkeresésben hatékonyan eljárni, repülőgépmotorokat és épületeket tervezni stb.

Egy bonyolult, sokváltozós helyzetben a MI ki tudja választani azt, ami az alkalmazó számára a bizonyos szempontok szerinti optimális megoldást jelenti. Ennek különösen a gazdasági döntéseknél lesz (már van) nagy szerepe. A „bot"-ok (chatelő robotok) a fárasztó kampányidőszakban politikusok helyett végzik el a munkát, a feltett kérdésekre helyettük válaszolnak. A kiberhadviselés során szoftverek feszülnek majd egymásnak, és az intelligensebb győz: megbénítja a másik hátországának ellátó rendszereit, sőt, legyőzi az ellenséges szoftvert...

\section{Vajon uralkodni fog-e fölöttünk?}


A leggyakrabban visszatérő kérdés, hogy a MI vajon idővel nem kerekedik-e fölénk, nem fog-e rajtunk uralkodni. E félelemnek az ad alapot, hogy a MI képes tapasztalatait felhasználva fejleszteni, tökéletesíteni önmagát; tanul az új helyzetekben, tehát nem csak az általunk szabott irányban fejlődik. Martin Rees, Nick Bostrom, Stephen Hawking, Elon Musk, Bill Gates és más, ismert tudósok is aggódnak emiatt. Szerintük e veszély akkor fog jelentkezni, amikor majd kifejlődik az általános mesterséges intelligencia (ÁMI), a szuperintelligencia, ami már mindenre képes lesz, amire az emberi elme, és ráadásul fölül is múlja azt. A legtöbb tudós e század közepére jósolja e lehetőség megvalósulását, de nem kevesen olyanok is vannak, akik szerint ez sohasem fog bekövetkezni.

Max Tegmark, az MIT professzora (Massachusetts Institute of Technology) és a Future of Life Institute elnöke is azok közé tartozik, akik e veszélyt reálisnak tartják, és az Élet 3.0 címú könyvében konkrétan leírja azt az elképzelt esetet, amikor az ÁMI átveszi az emberi társadalom fölött a hatalmat. ${ }^{1}$ E veszélyt valósnak véve, egy olyan nemzetközi mozgalmat kezdeményezett, amely megszabja, hogy melyek azok a területek és kutatási profilok, ahol megálljt kell parancsolni. (Tekintve azonban, hogy a MI fejlesztéséhez egyre komolyabb hadászati és stratégiai érdekek is füződnek, a nemzetközi nagyhatalmi szembenállás miatt e törekvéseket igen nehéz megvalósítani.)

E kérdés kapcsán (ne bántsd az embert!) merül fel a MI erkölcsi programozásának feladata és lehetősége. A deep learning már ma is ad egyfajta megoldást: az algoritmust a napi sajtón és a világirodalom legismertebb, legbecsesebb művein tréningeztetve előáll egyfajta értékkeverék... De aligha hihető, hogy ez a mix jó alapul szolgál majd az emberiség sorsát a kezében tartó ÁMI számára. A téma újabb buktatója, hogy az emberi viselkedés és gondolkodás jelentős mértékben irracionális. ${ }^{2}$ Ha elfogadjuk a feltételezést, hogy elménk egyes alrendszereinek preferenciái inkompatibilisek egymással, a vágyaink, óhajaink kielégítésére törekvő ÁMI megoldhatatlan feladattal találja szemben magát. Nem is beszélve arról, amikor ezeket még politikai érdekek is áthatják és variálják. A feladat megoldhatatlannak tűnik az emberi magatartások és erkölcsi elvek szinte végeláthatatlan változatossága és ellentmondásossága miatt is. ${ }^{3}$

Steven Pinker, a Harvard pszichológus professzora nem tart attól, hogy az ÁMI az emberrel szemben ellenséges lenne. Véleménye szerint a jellegzetes MI disztópiák „a szúklátókörű alfa-hím pszichológia kivetítődései az intelligencia koncepciójára". (Azaz: az intelligensebb lény hatalmát mások meghódítására használja fel.) A rettegők téves platformon állnak: azt hiszik, hogy az intelligenciából következik a dominancia vágya. ${ }^{4}$ Ez megnyugtató.

\section{A szuperintelligencia megvalósulását még komoly akadályok nehezítik}

A MI jövőjének és a szuperintelligencia létrehozásának/létrehozhatóságának megítélése a filozófia síkján a tudat eredetét és jellegét érinti. Ha metafizikai állásponton vagyunk, a MI-nak nem lehet tudata, de ha a tudat emergens jellegét valljuk, akkor az anyag egy igen magas bonyolultságának szintjén az önmagától ki kell, hogy alakuljon. Különösen figyelemreméltóak e tekintetben Max Tegmark nézetei, aki szerint a tudat, ugyanúgy, mint az intelligencia, „anyagfüggetlen”, azaz kialakulásuk nem kötődik a szerves anyaghoz. ${ }^{5}$ De ezt a szemléletet támasztja alá Michio Kaku elmélete is, miszerint a tudat kialakulása egy kontinuum mentén vizsgálható, ahol az egyes lépcsőfokokat a külső hatásokra adott viszszacsatolások jelentik, melyek száma az élőlények fejlettségével párhuzamosan egyre nő, és így a tudat (és az öntudat is) fokozatosan fejlődik ki. ${ }^{6}$ 
Ahhoz, hogy meg tudjuk ítélni, a MI valaha is utolérheti-e és lehagyhatja-e az emberit, tekintsük át az emberi és a gépi gondolkodás főbb jellemzőit. Az emberi agy működési elve, „adatfeldolgozása” alapvetően analóg és analitikus: a neokortex mintafelismerő egységei egyszerre dolgoznak; a neuronok "outputja” digitális, de a dendritek az inputokat analóg módon dolgozzák fel, asszociációk révén. A gép "gondolkodása”, müködési elve ezzel szemben szekvenciális: folyamatos, sorozatos, sorrendi; minden lehetőségen végig kell mennie. Óriási logikai fákat épít fel a lehetséges kimenetekből, és minden lehetőséget figyelembe vesz. Még a neokortex réteges mintázatát utánzó deep learning múködése is szekvenciális. Ahol előnye van az emberi agygyal szemben, azt brutális számítási kapacitásának köszönheti. Ezért képes legyőzni a sakk vagy a go világbajnokait: minden adott helyzetben minden lehetséges kimenetelt figyelembe vesz. (De a gép nem élvezi a játékot, nem tud improvizálni, nem képes egy-egy váratlan lépéssel megzavarni az ellenfelet. Ugyanakkor tud stratégiát alkotni, ami a go-játék alapfeltétele.) ${ }^{7} \mathrm{Ha}$ az emberi agyat a szekvenciálisan múködő komputerrel próbálnánk meg utánozni, egy egész városrész nagyságú számítógépre lenne szükség, a mikroprocesszorok hütésére pedig egy nagy folyóra. ${ }^{8}$

Az emberi agy további, egyelőre behozhatatlannak tűnő előnye a kontextusba helyezés képessége. Az emberi intelligenciának hihetetlenül nagy az általánosítási és az alkalmazkodási képessége. Könnyen tudunk a különböző kontextusok között váltani, és könnyedén kezeljük a váratlan szituációkat. Ez a MI esetében elképzelhetetlen. Ezért tartja úgy Kate Darling, az MIT kutatója, hogy a gépi intelligencia sohasem fogja utolérni az emberit, ugyanis az nem a fejlődésnek (fejlesztésnek) egy alacsonyabb fokán áll, hanem másfajta. ${ }^{9}$

Kiterjedt kutatások folynak az emberi agy „szkennelésére”, lemásolására. (Amerikában pl. 2013 óta nagyméretű kormányprogram, az EU-ban ugyancsak 2013 óta közösségi program finanszírozza e kutatásokat.) Ezek célja az, hogy ha képesek leszünk az egyes agyi folyamatok digitális megismétlésére, utánzására, akkor abból adódik majd a gépi továbbfejlesztés lehetősége. Az eredmények egyelőre eléggé kiábrándítóak. ${ }^{10} \mathrm{~A}$ „szkennelést” megnehezíti, hogy az egyes agyi funkciók, az agy működése nem köthető egy-egy agyterülethez; azokban az összes többi részt vesz. („Megosztott adatbázis"?)

Ha e kutatások célra vezetnek, abból az is következik majd, hogy agyunk lemásolható lesz egy adathordozóra, és ily módon megnyílik előttünk a digitális öröklét lehetősége. És mivel a test klónozása már ma is megvalósítható, beköszönt majd a tényleges öröklét korszaka. Mivel az emberi létezésnek az egyszerisége, megismételhetetlensége, azaz a halál ad értelmet, az öröklét beláthatatlan egzisztenciális és pszichológiai komplikációkhoz vezetne.

A technológia mai szintjén a virtuális és kiterjesztett valóságok (VR, AR) és az avatárok (tetszés szerinti alakban való internetes megjelenésünk lehetősége) feszegetik egzisztenciális korlátainkat. Itt az a veszély fenyeget, hogy vajon nem keverik-e össze az emberek a valótlan világot a valóval; a digitálist az analóggal? A felmérések erre érdekes és jellemző választ adnak. „Az X és az idősebb generációk vagyis azok, akik 1980 előtt születtek - két külön térként értelmezik a valós és a virtuális világot, és az előbbit érzik természetesnek, komfortosnak. Hovatovább ők úgy gondolják, hogy az analóg világ értékesebb is a digitálissal szemben." 11 A folytatást már kitalálhatjuk: „A fiatalabb, Y, Z és Alfa generációk $\langle. .$.$\rangle többségének értelmezhetetlen a két dimenzió szétválasztása: nekik egyetlen világ létezik,$ amely valós, és szerves része a digitalizáció." A Magyar Telekom megbízásából végzett kutatás arra is rámutatott, hogy egyes hiedelmekkel ellentétben a digitalizáció nem elidegenít, hanem számottevő humanizációs és pozitív kulturális hatása van. ${ }^{12} \mathrm{Az}$ internet fejlődésének most kezdődő, harmadik korszakára az lesz jellemző, hogy tetszés szerinti alakokban jelenhetünk meg a világháló virtuális valóságában. (Az internetes játékokból már tudható, hogy miről van szó.) Tehát virtuális énjeinkkel 
népesítünk majd be virtuális világokat... Vajon mindez megmarad-e a szórakoztatás/szórakozás keretei között? Első hallásra ez egyenes út a skizofréniához...

Martin Rees szerint nagyon valószínűtlen, de nem elképzelhetetlen, és a fizika törvényeinek nem mond ellent, hogy világunk egy hatalmas intelligencia virtuális világa, melyben valamennyien virtuális szereplők vagyunk. Most e „játék” tovább folytatódik, ki-ki megteremtheti a saját virtuális világát.

\section{A MI hatása mindennapi életünkre, munkánkra}

A MI felmérhetetlenül sok vonatkozásban és területen segíti és megkönnyíti az életünket, a munkánkat. De egyre szorongatóbb az érzés: vajon nem tesz-e minket feleslegessé? Nem következik-e be hamarosan az, amit Huxley a 2500-as évekre vizionált, hogy a feleslegessé vált, munkájuktól és az élet értelmétől megfosztott emberek drogokkal érik el a boldogságot és elégedettséget? Egy sokat idézett tanulmány szerint az elkövetkező évtizedben az amerikai munkahelyek közel felét automaták fogják felváltani. ${ }^{13}$ Martin Ford amerikai kompjútertudós a jövőre 75 (!) százalékos munkanélküliséget jósol. ${ }^{14}$ A korábbi folyamatokkal ellentétben - amikor a gépesítés és automatizálás a fizikai munkát váltotta fel, és a munkaerőfelesleget a szolgáltatások szívták fel -, jellemzően a szolgáltatásokban várható a legtöbb munkahely megszűnése, a szövegszerkesztők és gépírók, ingatlanügynökök, műszaki írók, eladók, könyvelők és auditálók, telemarketingesek munkáját a MI nagy valószínűséggel feleslegessé teszi. Legkevésbé azokat a tevékenységeket fenyegeti, amelyek közvetlenül az emberrel kapcsolatosak: rekreációs terapeuták, fogászok, sportedzők, lelkészek, szerkesztők és kiadók munkáját... Csak az érzelmi hátterü, empátiát igénylő, közvetlenül az emberekkel foglalkozó munkák maradnak meg. ${ }^{15}$

A MI átalakítja a gazdaság szerkezetét is, a logisztikai és adminisztratív tevékenységeket automatizálja, és a kreatív tevékenységekből származik majd a jövedelem nagyobb hányada. A távmunka és a távoktatás egyre szélesebb körben fog terjedni, ezekkel azonban itt most nem foglalkozunk, mert a téma inkább az internettel kapcsolatos. (Valójában a két terület összemosódik, az internetes múveletek egyre gyakrabban alapulnak mesterséges-intelligencia-jellegű algoritmusokon.)

E témát általánosabb összefüggésbe helyezve az a kérdés merül fel, hogy a MI a műszaki fejlődésnek egy újabb szakasza, és úgy tekintsünk-e rá, mint ahogy korábban mondjuk a gőzgépre, vagy a nagyobb technikai újításokra, amikor rendre felmerült a kérdés, hogy azok kiszorítják az embert a munkából és jelentős változásokat okoztak az életmódban, vagy egy újabb jelenségről van szó. Sundar Pichai, az Alphabet (Google) elnöke úgy fogalmazott, hogy a MI nagyobb hatású technológia, mint annak idején a tűz, később pedig a villanyáram felfedezése volt. Ám szerinte nem kell félnünk tőle; lehetővé teszi, hogy agyunkat, intelligenciánkat az újabb, még magasabb minőségű feladatok megoldására mozgósíthassuk. ${ }^{16}$ (Ez igaz lehet az értelmiségi rétegre, de az emberek döntő része nem lesz képes arra, hogy a MI adott szintjén túlmutató, kreatív munkát végezzen.) 


\section{Emberi mivoltunk perspektívái}

Végül, tekintsük át azt a kérdést, mivé tesz minket a MI, veszélyezteti-e emberi mivoltunkat? E téren a legrégebbi, tudományosan legbeágyazottabb elképzelés a szingularitás, és az azon alapuló transzhumanizmus. Eszerint az elvont gondolkodás megjelenésével (kb. 70-100 ezer ével ezelőtt) a Homo sapiens letért a biológiai evolúció csigalassúságú pályájáról és azóta a kulturális evolúció gyors sztrádáján halad. A MI megjelenése e száguldást még tovább gyorsítja. E feltételezés szerint a gépi intelligencia utol fogja érni az emberit, és ekkor a kettő egyesüléséből egy új, transzhumán lény születik. A szingularitás fogalmát még Neumann János vetette fel az ötvenes években; mai legismertebb képviselője Ray Kurzweil, az Alphabet mérnök-zsenije. ${ }^{17}$

Kurzweil az emberi és gépi intelligencia összeolvadását egy univerzális evolúciós kontextusba helyezi. Az intelligenciát az információval azonosítja, és szerinte az egyre komplexebb formákban testet öltő információ elterjedése az Univerzum intelligenssé válásához fog vezetni. Ennek kezdete az volt, amikor az információ megjelent az atomi struktúrákban, majd a DNS-ben, folytatódott ez az agy, majd az információs technológia kifejlődésével, most vagyunk az emberi és a gépi információ összeolvadásának szakaszában, és ezután következik a 6. korszak, a világegyetem öntudatra ébredése, amikor az óriási mértékben kiterjesztett (túlnyomóan nem biológiai) emberi intelligencia elterjed az univerzumban; a világegyetemben létező anyag és energia átitatódik intelligens folyamatokkal és tudással. Ez az elképzelés nem egyedülálló, hasonlókat vallott Teilhard de Chardin is, amikor arról beszélt, hogy végső soron minden - tudás, energia, anyag - egy isteni egyesülés során eggyé válik, az lesz az "Omega Pont”.

A szingularitás, az emberi és gépi intelligencia eggyéválásának útját egyengeti a kiberfilozófia. Legnagyobb hatású képviselője, Gotthard Günther törekvése arra irányul, hogy a szubjektum filozófiai fogalmának fellazításával, relativizálásával egyengesse az élő és élettelen, ember és gép közötti különbségeket. „Meg kell találni az öntudat és a szubjektivitás formál-logikai kritériumát, amely aztán matematizálható, és a számítógépes operációkban felhasználható" - írja Günther. ${ }^{18}$ Elméletét egy nem-tradicionális, nem-arisztotelészi logika és ontológia kifejlesztésével alapozza meg. A szubjektumot szétválasztja nem-felosztott és felosztott változatra. A szubjektum első formája az egyén, a második pedig „az általános szubjektivitás interszubjektív médiuma”. (Azaz a sok egyén által alkotott általános szubjektivitás.) Ezzel a szubjektum, a szubjektív fogalmát demisztifikálja, deszakralizálja és természettudományos alapokra helyezi, és a szubjektív tulajdonságok (öntudat, ön-reflektáló képesség, gondolkodás, döntéshozatal stb.) előállítását mesterségesen is lehetségesnek tartja.

Bár a kozmikus perspektívákat nem téveszthetjük szem elől, a jelenkor kutatóinak arra kell választ adniuk, hogy mi is az ember, embermivoltunk meghatározásában milyen szerepet játszik a technológia. Pokol Béla $A$ mesterséges intelligencia társadalma című könyvében az emberi és gépi intelligencia ontológiai kérdését Hartmann létrétegeivel összefüggésben tárgyalja. Véleménye szerint a gépi intelligencia nem lehet a hartmanni „értelmi” létréteg szerves folytatása; az csak a fizikai létrétegből közvetlen evolúcióval, a biológiai és az érzelmi létrétegek kihagyásával, átugrásával válhat önszervező, önálló entitássá. Major Gyöngyi Az emberi létkoncepció újraértékelése (Az ember a mesterséges intelligencia korában) c. tanulmányában így fogalmaz:

„Egy olyan identitás lehetőségét keressük, amely nem a »kultúra és természet « oppozíció meghaladásának igényében válik értelmezhetővé, hanem a két entitás összeolvasztása he- 
lyett azok komplementer viszonyrendszerének értelmezhetőségét képes megtartani, miközben a legtágabban értelmezhető kultúrát a technológia szinte teljességében leuralja. Az antropológia vonatkozásában itt már nem a biológia-kultúra ellentétpár a releváns, hanem az ezek szintézisében értelmezett ember az egyik, s az emberről levált gépi/mesterséges kultúra a másik oldalon. Olyan nyitott antropológiát keresünk tehát, mely nem az ember meghaladása mellett érvel, azonban - elsősorban az MI realitás irreverzibilitásának következtében az emberi mivolt újrafogalmazását, mint kikerülhetetlen feladatot fogalmazzuk meg. Amenynyiben pedig a technológia és a létezés közötti új egyensúlymodellt keresünk - olyan modellt, amely képes megakadályozni a virtualitás serpenyőjének végleges kibillenését -, akkor felvetjük annak lehetőségét, hogy az egyensúlyozó serpenyő hatékonysági potenciálját a női létezési attitűdök hangsúlyos reprezentáltságával kíséreljük meg biztosítani." ${ }^{19}$

Technika és ember viszonyát Heidegger értékelte újra a múlt században. Elítélte a nyugati filozófia egyoldalú, metafizikus világszemléletét, mely a technikát általában a célok eléréséhez használt semleges eszköznek tartotta. Ezzel szemben szerinte a technika változása világszemléletünk megváltozásához vezet. ${ }^{20}$ A technikához fűződő „metafizikus” viszonyunkban Bernard Stiegler francia filozófus technofilozófiája hozott átütő erejű változást. Stiegler a technikát egyenesen „antropológiai alkotóelemnek" tekinti, amely kulcsszerepet játszott emberré válásunkban. ${ }^{21}$

James Lovelock, a Gaia-elmélet megalkotója abban reménykedik, hogy a MI segítségünkre lesz a pusztuló ökoszisztémák megmentésében és a klímaváltozás elhárításában - ehhez azonban ő is az emberi és a gépi intelligencia egyesülését feltételezi. ${ }^{22}$ Hankiss Elemér szép megfogalmazásában az öntudatlan és sötét Univerzum általunk ismer önmagára, az ember visz értelmet, szépséget és jóságot a világmindenségbe. ${ }^{23}$ Magasztos szerepünk csak még tovább fokozódhat, ha értelmünk, emberi mivoltunk tovább gazdagodik az általunk létrehozott technológiával. 


\section{Jegyzetek}

${ }^{1}$ TeGmaRk Max: Élet 3.0. Embernek lenni a mesterséges intelligencia korában. Budapest: Hvg könyvek, 2018.

2 Lásd erről KAHNEmAn Daniel: Gyors és lassú gondolkodás. Budapest: Hvg könyvek, 2013.

${ }^{3}$ A célok és értékek témájáról Tegmark Élet 3.0 címú könyvében találhatunk egy rendkívül izgalmas fejezetet.

${ }^{4}$ Steven Pinker tanulmánya a Brockman által szerkesztett kötetben (BrocKMAN John: Possible Minds. 25 Ways of Looking at Al. Penguin Books, 2020.). Lásd erről még: Bostrom Nick: Ethical Issues in Advanced Artificial Intelligence. web, 2003. https://nickbostrom.com/ethics/ai.html

${ }^{5}$ Tegmark Max I. m.

${ }^{6}$ KAKU Michio: Az elme jövője. Budapest: Akkord, 2014.

7 E témáról lásd: KURZWEIL Ray: How to Create a Mind. New York: Viking Penguin Book, 2012. web.; KaKu I. m. és EAgLeman David: Az Agy. A te történeted. Budapest: Akkord, 2017.

${ }^{8}$ KAKU I. m. 271. o.

9 DARLING Kate: The New Breed: What Our History with Animals Reveals. New York: Henry Holt\&Co., 2021.

${ }^{10}$ A Valóság 2019. novemberi számában megjelent tanulmányomban (A mesterséges intelligenciáról - halandóknak) erről részletesen beszámoltam (Kıss Károly: A mesterséges intelligenciáról - halandóknak. // Valóság, 2019, №12, 15-26. o.). Lásd: Kiss Károly: 25 tudós a mesterséges intelligenciáról. // Valóság, 2021, №11, 15-26. o.

${ }^{11}$ SOMOGYı Orsolya: A fiatalok nem választják el a digitalizált teret az analóg világtól. // Magyar Idők, 2018. febr. 12. (A Kantar Hoffman cég kutatása a Magyar Telekom megbízásából.) web.

${ }^{12}$ Uo.

${ }^{13}$ The Economist, January 18th 2014.

${ }^{14}$ Uo.

${ }^{15}$ Uo.

${ }^{16}$ Az Economist 2020. június 13-i technológiai melléklete.

17 Lásd erről: KURZwell Ray: A szingularitás küszöbén. Budapest: Ad Astra, 2013. web. https://docplayer.hu/184766672-Ray-kurzweil-a-szingularitas-kuszoben.html (Megtekintés: 2021.12.11.)

${ }^{18}$ GÜNTHER Gotthard: Cyberphylosophy. BCL-Reports. English Collection, not complete. (Ed. Rudolf Kaehr, prepared by Prof. Eberhard von Goldamer) 2004: 8. o.) http://www.vordenker.de/rk/rk_Cyberphilosophy_2003.pdf.

${ }^{19}$ MAJOR Gyöngyi: Az emberi létkoncepció újraértékelése (Az ember a mesterséges intelligencia korában). In: Individualizáció, személyiség és mesterséges intelligencia (Szerk. Kiss Károly). Budapest: L'Harmattan-KNRF 2022 (Megjelenés alatt).

20 HeIDEGGer Martin: Már csak egy Isten menthet meg bennünket. // Gondolat-jel, 1993. 1-11. (A Spiegel által 1966. szept. 23-án Heideggerrel készített interjú utánközlése.)

${ }^{21}$ VACCARI Andres-BARNETT Belinda: Bernard Stiegler and the Question of Technics. // Transformations, 2009, № 17 (electronic journal), valamint a francia nyelvü Wikipedia.

22 Lovelock James-APPLEYARD Bryan: Novacene - The Coming Age of Hyperintelligence. The MIT Press, 2019.

${ }^{23}$ HANKISS Elemér: Az emberi kaland. 2014. 